\title{
Finance and the Earth system - exploring the links between financial actors and non-linear changes in the climate system
}

Victor Galaz' Beatrice Crona, Alice Dauriach, Bert Scholtens \& Will Steffen

\begin{tabular}{|c|c|}
\hline Date of deposit & $13 / 11 / 2018$ \\
\hline Document version & Author's accepted manuscript \\
\hline Access rights & $\begin{array}{l}\text { (c) } 2018 \text {, Elsevier Ltd. This work is made available online in } \\
\text { accordance with the publisher's policies. This is the author } \\
\text { created, accepted version manuscript following peer review and } \\
\text { may differ slightly from the final published version. }\end{array}$ \\
\hline $\begin{array}{l}\text { Citation for } \\
\text { published version }\end{array}$ & $\begin{array}{l}\text { Galaz, V., Crona, B., Dauriach, A., Scholtens, B., \& Steffen, W. } \\
\text { (2018). Finance and the Earth system - exploring the links } \\
\text { between financial actors and non-linear changes in the climate } \\
\text { system. Global Environmental Change, 53, 296-302. }\end{array}$ \\
\hline $\begin{array}{l}\text { Link to published } \\
\text { version }\end{array}$ & https://doi.org/10.1016/i.gloenvcha.2018.09.008 \\
\hline
\end{tabular}

Full metadata for this item is available in St Andrews Research

Repository at: https://research-repository.st-andrews.ac.uk/

\section{St Andrews Research Repository}


1 Finance and the Earth system - exploring the links

2 between financial actors and non-linear changes in

3 the climate system 
5 Financial actors and capital play a key role in extractive economic activities around

6 the world, as well as in current efforts to avoid dangerous climate change. Here, in

7 contrast to standard approaches in finance, sustainability and climate change, we

8 elaborate in what ways financial actors affect key biomes around the world, and

9 through this known "tipping elements" in the Earth system. We combine Earth system

10 and sustainability sciences with corporate finance to develop a methodology that

11 allows us to link financial actors to economic activities modifying biomes of key

12 importance for stabilizing Earth's climate system. Our analysis of key owners of

13 companies operating in the Amazon rainforest (Brazil) and boreal forests (Russia and

14 Canada) identifies a small set of international financial actors with considerable, but

15 as of yet unrealized, globally spanning influence. We denote these "Financial Giants",

16 and elaborate how incentives and disincentives currently influence their potential to

17 bolster or undermine the stability of the Earth's climate system.

18

19 Keywords: climate change; tipping elements; financial systems; telecoupling;

20 sustainable finance; deforestation.

21 Word count: 3,830 words (main text) $+1,000$ (references)

22 Figures and Tables: 2 figures, 4 tables.

23 References: 52.

24 Supporting Information: 18 pages. 


\section{Introduction}

Humans have become the main driving force behind global environmental change at unprecedented scales (Rockström et al. 2009; Steffen et al. 2015; Worm and Paine 2016). However, not all of the world's regions are affected by, nor affect, the climate system in the same way. A number of specific biomes and biogeophysical processes have been highlighted as exceptionally important for global climate stability due to their ability to affect feedback dynamics in the Earth system (Steffen et al. 2015). These different biomes and Earth system processes have variously been conceptualized as "sleeping giants" in the carbon cycle (Steffen 2006), "tipping elements" in the Earth system (Lenton et al. 2008), and "planetary-scale tipping points" (Barnosky et al. 2012; Lenton and Williams 2013). Changes in the stability of tipping elements are increasingly being accounted for in climate models (Cornell et al. 2012), and include, among other things, deforestation (Steffen et al. 2004). Forest biomes are of particular importance as tipping elements because of the nature of their biogeophysical climate feedbacks. Of all the major forests on the planet, the Amazon and the boreal forests are of particular importance; more so than temperate forests and Asian rainforests (Snyder et al. 2004; West et al. 2011; Steffen et al. 2015, see also Supporting Information 1). Their disproportionate influence on climate stability suggest that in order to safeguard a prosperous future for humanity, society needs to consider approaches that, in addition to emission reductions, maintain and enhance resilience of these forested biomes (and other tipping elements) (Schellnhuber et al. 2016; Rockström et al. 2017). 
Financial actors, such as international development banks, institutional investors, credit rating agencies and international commercial banks, are increasingly interested in the financial risks of climate change and associated changes in ecosystems. In

51 parallel, scholarly interest in the climate-finance nexus has also increased. This

52 includes work on e.g. "green bonds" and other impact investments, assessment of

53 climate-related financial risk and insurance mechanisms, ESG measures and differential performance of socially responsible investment portfolios, as well as drivers of responsible investment (Collier et al. 2009; Sievänen et al. 2013; Revelli and Viviani 2015; Müller and Kreuer 2016; Battiston et al. 2017; OECD 2017; Scholtens 2017). Two gaps emerge in relation to this development, particularly in the finance industry.

60 First, while the growth in the "green bonds" market is impressive, it represents only a

61 fraction of global capital flows: less than $0.2 \%$ of debt securities issued globally

62 (OECD 2017 p. 23). Second, avoiding dangerous climate change requires taking 63 account of the non-linear, threshold dynamics encompassed by the tipping elements 64 outlined above (Steffen et al. 2018). However, most current "green" financial 65 initiatives focus primarily on various ways to reduce emissions through e.g. 66 divestment, or renewable energy, energy efficiency and low-carbon transport 67 investments - the latter three together representing $79 \%$ of the green bond market 68 (OECD 2017 p. 25).

70 Thus, while reduction of greenhouse gas (GHG) emission is crucially important to 71 avoid dangerous climate change, it is not enough (Steffen et al. 2018). Bolstering the 72 capacity of key tipping elements to prevent them from "tipping" is equally essential. 
73 Ignoring the non-linear dynamics encompassed by tipping elements could have

74 detrimental effects on the ambitions set by the Paris Agreement, and threaten the

75 achievement of the Sustainable Development Goals (Schellnhuber et al. 2016;

76 Rockström et al. 2017). It also has repercussions for economic stability and financial

77 risk (Lawrence and Vandecar 2015; Chatterjee et al. 2016; UNEP Inquiry 2016;

78 Battiston et al. 2017; Scholtens 2017).

79

80 This paper combines Earth system and sustainability science with corporate finance,

81 to explore how the links between financial investment and non-linear climate

82 dynamics can be analyzed. This is not only of interest to policy and financial actors,

83 but also for scholars interested in understanding how key global actors affect the

84 climate system either through their position in global markets ( $c f$. Österblom et al.

85 2015), or through processes of "telecoupling" (Liu et al. 2015). Telecoupling refers to

86 the connections between geographically separate biomes and economic activities.

87 These global connections between human and natural systems have both

88 socioeconomic and environmental effects (Liu et al. 2015). In the context of finance

89 and the biosphere, such telecoupling emerges from the fact that financial investments

90 and investment policy decisions may have cross-continental social and ecological

91 effects. Documented examples include international investments in companies

92 associated with land use change through e.g. palm oil production in Borneo (WWF

93 and EnviroMarket 2012), or sustainable investment policies by major pension funds

94 which increase the pressure on corporations to improve their environmental, social

95 and governance performance (Galaz et al. 2015). 
97 We propose a novel methodology to identify the ways in which financial actors and flows of capital are linked to biomes associated with key tipping elements in Earth's

99 climate system and ask:

100

a) Is it possible to identify a limited set of financial actors mediating flows of capital to known tipping elements in the Earth's climate system?

b) What incentives and mechanisms of influence exists for these actors to alter investments in support of global climate stability?

105

106

\section{Methods and data}

\subsection{Selection of cases}

108 A number of regional biomes and associated Earth system processes have been

109 proposed as tipping elements, whose dynamics, if disrupted through multiple

110 feedbacks in the Earth system, could contribute to the destabilization of the global

111 climate system (Lenton et al. 2008 and references therein; Steffen et al. 2018). Here

112 we select two of these known biomes - the Amazon tropical forest in Brazil and the

113 boreal forests in Canada and Russia (Figure 1). The resilience of these biomes is

114 linked to both climatic and non-climatic anthropogenic drivers, such as deforestation

115 driven by economic activities and their associated financial inputs (see Supporting

116 Information 1 for details and known threshold uncertainties).

117

118 [Figure 1 placeholder]

119 
120 It should be noted that market structure, financing of corporate operations, and a

121 firm's influence on key drivers of change of tipping elements, can differ considerably

122 depending on the sector and the country of interest. Table 1 summarizes the corporate

123 structure in the selected biomes, and shows the level of concentration in each sector,

124 across both publicly listed companies and in private and other companies (see

125 Supporting Information 2 and 3, as well as tables S1 and S2 for limitations, detailed

126 data and information about available data depending on company type). Table 1

127 shows that concentration is high in all four sectors and motivates our focus on the

128 major owners of the dominant companies operating in the biomes.

[Table 1 placeholder]

131

132 As noted earlier, our selection of biomes is based on the strength of biogeophysical

133 feedbacks of these forests to the climate system. As such, the sample provides a

134 strategic first selection to illustrate the strength of the methodology as well as the kind

135 of insights provided. The methodology could also be applied to assess links between

136 financial actors and other critical ecosystem services or "planetary boundaries", such

137 as biodiversity. We leave this for future research.

138

\subsection{Different finance modes of importance for} mapping links between the biosphere and financial

\section{sectors}

142 Financial actors contribute to biome modifications by financing the extractive

143 activities of companies. Financing generally occurs through a combination of loans 
144 and bonds, and through stock (also known as equity), where stocks are issued either

145 through an initial public offering or so-called seasoned offerings (Mayer 1990; Rajan

146 and Zingales 1995; Booth et al. 2001). Hence both equity and debt are important for

147 understanding the links between financial actors and our focal biomes.

149 However, from a finance perspective, there is a fundamental difference between 150 stocks, and bonds and loans. Bonds and loans relate to a usually fixed claim on part of

151 the revenues of a project or firm. With debt, financiers can reveal their preference

152 with origination: they may withhold capital from environmental laggards, thus

153 signaling discontent and pushing down prices. Financiers may also include covenants

154 in the debt contract relating to environmental performance. Violation of a covenant

155 may trigger default. Stock on the other hand, holds a residual claim on the firms'

156 profits and has ownership rights allowing stockholders to vote about strategic

157 decisions of the firm and the appointment of top executives. As such, the role of stock

158 is more prominent than that of other types of finance in the governance of the firm

159 (Edmans 2014). In addition, stock ownership also determines the potential degree to

160 which any one investor has influence over corporate decisions, operations, and thus

161 strategic development (Apple et al., 2016).

162

163 There are three main mechanisms by which influence can be achieved by

164 shareholders: voting (or proxy voting in the case of investment managers, Dam and

165 Scholtens 2013); direct engagement with management, either informally or through

166 systematic engagement (Dimson et al. 2015); and divestment (or the threat of it),

167 which may push stock prices down and signal discontent by investors with the

168 corporate governance of the firm (Edmans 2014). 
170 Mapping the ownership of financial assets in firms, the capital flows from financial

171 actors to companies, and the specific economic activities of firms on the ground is not

172 straightforward due to severe limits in the availability of financial data. While data on

173 shareholders is freely available for publicly listed companies, data on loans is not

174 generally easily accessible due to the opacity of banks' balance sheets, especially their

175 loans section. Ownership of private firms is in addition highly opaque (Morgan 2002;

176 Flannery et al. 2004; Stiroh 2006). Limited access to financial data is not a problem

177 exclusively for our analysis, but an issue for studies in this domain in general (Galaz

178 et al. 2018).

179

180 Given the limited accessibility of detailed debt data, and the influence associated with

181 stock ownership, our main analysis uses equity data and maps the ownership of

182 financial actors in key corporations that currently affect the ecological dynamics of

183 our focal biomes. We also assess the sensitivity of the firms to financiers by

184 calculating the debt to capital ratio for all companies in our sample, and compare

185 them to industry-wide averages (Damodaran 2017).

186

\subsection{Data analysis}

188 To assess linkages between financial systems and tipping elements in a systematic

189 way, we develop an interdisciplinary and exploratory methodology that combines

190 insights from the Earth system and sustainability sciences with corporate finance. The

191 details, as well as limitations, can be found in Supporting Information (2), and include

192 five steps: a) identification of the main proximate drivers of land-use change in each

193 biome (sensu Geist and Lambin 2002); b) identification of the most important 
194 industrial sectors associated with these drivers in the selected biomes; c) identification

195 of the largest companies in each sector in terms of market share; d) data analysis of

196 the ownership in selected strategic companies; and e) identification of the prevalent

197 stockholders, that is, financial actors with ownership in at least one company

198 operating in each of the selected biomes and sectors linked to tipping elements.

199

200 The selection of companies in c) is based on their market share in the sector of interest

201 only, without incorporating any company-specific environmental assessment. Several

202 of the companies in our analysis have deforestation policies in place, but are included

203 by virtue of their size and market dominance. By being vertically integrated and by

204 providing enhanced market access to a vast amount of producers (particularly in

205 Brazil), we argue that selected companies can influence the rest of the supply chain,

206 as well as have spill-over effects on market competitors. The chosen forestry

207 companies in Canada and Russia control a large landbank and represent a substantial

208 revenue share in the sector, therefore making their forest management policies crucial

209 to forest degradation and forest cover loss.

211 As we elaborate below, the stockholders identified in e) can influence drivers of

212 environmental change in multiple regions at the same time. Through their investments

213 policies or engagement strategies they could therefore in principle affect multiple

214 known tipping elements simultaneously.

216 Analysis of ownership is based on data from the Orbis database which contains

217 information on over 200 million companies worldwide (Bureau van Dijk 2017). Note

218 that identification of prevalent stockholders is only possible for listed companies and 
219 private companies with known owners. For several private companies in our selection

220 (7 out of 29 companies), no information about shareholders is available through

221 databases like Orbis. We calculate the debt ratio as the book value of debt (both long-

222 term and short-term), divided by total book value of debt and shareholders' equity

223 (based on Damodaran 2017). For detailed information on calculations and full list of

224 company ratios, see Supporting Information (5).

\section{Results and Discussion}

\section{1. "Prevalent stockholders": who are they and why} are they important?

229 Large financial actors have been shown to possess significant corporate control

230 globally (Vitali et al. 2011; Fichtner et al. 2017). Until now, however, such control

231 has not been linked to changes in biomes associated with tipping dynamics in the

232 Earth's climate system. Table 2 lists what we denote as prevalent stockholders, and

233 estimates of their "blockholding" power in key companies operating in each selected

234 biome associated with a tipping element (see Supporting Information 4 for more

235 details). We label these owners as "Financial Giants" because of their size and

236 potential to influence companies. They are ranked according to the number of

237 companies in which they own shares, here denoted "ownership breadth" (see Fichtner

238 et al. 2017). Blockholding generally refers to shareholding of at least 5\% (Edmans

239 2014), and is in the finance literature generally assumed to entail considerable

240 influence over corporate governance. 
244 As our data show, these prevalent stockholders include a variety of financial actors

245 ranging from international banks to institutional investors such as insurance

246 companies, asset managers, and pension funds. All prevalent stockholders in Table 2

247 have shares in five or more of the selected companies. Six have individual

248 blockholdings ( $\geq 5 \%$ of the shares) in at least one company. Two thirds are based in

249 the US, including five of the top seven actors (in terms of ownership breadth).

251 Stockholders can coordinate their voting on issues related to corporate control

252 (elaborated below). Therefore, it is also interesting to assess these actors' aggregated

253 influence in each of the selected biomes. In Figure 2, we choose a 10\% ownership

254 level to indicate considerable voice in corporate governance that could be mobilized

255 by these actors. This is the level usually applied to identify so-called "insiders" in the

256 US corporate context. We also calculate the aggregated ownership of different

257 coalitions based on possible patterns of potential collaboration between stockholders

258 (elaborated below).

260 [Figure 2 placeholder]

262 Our analysis shows that the largest passive asset managers in the world, the "Big

263 Three" (Blackrock, Vanguard and State Street) together hold stocks above the 10\%-

264 threshold in 2 of 8 companies in the Amazon biome, 2 out of 16 in Canada's boreal

265 forests, and 3 of 5 in Russia's boreal forests. The "Big Three" are known to

266 collectively represent the largest corporate stockholders in the US (Fichtner et al. 
2017), but their ownership has never before been linked to their influence on climate stability.

The 16 identified prevalent stockholders have an even larger aggregate potential

271 influence. Findings indicate that these reach above the 10\%-threshold in 3 of 8

272 companies in the Amazon, 5 of 16 in Canadian boreal forests, and 3 of 5 in Russian

273 boreal forests. In seven of the 29 companies, the prevalent stockholders collectively

274 represent the largest single stockholder.

A complementary measure of their influence relates to the concentration of equity ownership in each of the selected companies. High concentrations of equity ownership (in this case a high value on the Herfindahl-Hirschman index) also indicates the latent influence of equity owners. As Table 3 shows, such concentration is substantial for companies in the beef sector in Brazil, for economic activities in

281 boreal forests in Canada and partly also in Russia (see also Supporting Information 4).

[Table 3 placeholder]

Figure 2 and Table 3 thus show that as a collective, the "Financial Giants", through their common blockholding power, have a previously ignored, yet considerable

287 potential influence in companies shaping biomes critical for the stability of the 288 climate system.

\subsection{Complementary mechanisms for influence}


291 The previous section focused on equity as a means for the financial sector to exert

292 influence over the fate of known tipping elements. Influence associated with

293 ownership is, however, only attainable in listed companies. To what extent ownership

294 influence alone is able to also translate into impacts on the sector as a whole, depends

295 to a large extent on the composition of listed and non-listed companies, with the latter

296 being more dependent on alternative funding. As mentioned above, debt is an

297 important alternative financing mechanism for companies. However, debtholders lack

298 control rights and have fewer means to influence corporate strategy (apart from

299 including covenants in the contracts).

300

301 Table 4 shows the total book debt to capital of the selected companies, presented per 302 sector and compared to industry averages. All our focal companies in the beef sector 303 rely heavily on debt. In the Canadian forestry sector a few companies (4) rely heavily 304 on debt (see Supporting Information 5 and Table S3 for details). The debt ratio in the 305 four sectors studied does not differ that much from global industry averages, as there 306 is much variation in these figures (Damodaran 2017; Appel et al., 2016).

\section{[Table 4 placeholder]}

310 In summary, the influence of "Financial Giants" on companies is considerable, but the

311 extent differs depending on sector, and where companies operate. The investors'

312 latent influence is largest in the beef and soy sectors associated with activities

313 modifying the Amazon tipping element, but the influence of the "Financial Giants" is

314 still substantive in the other industries and regions. All four sectors show relatively

315 high concentration and dominant power in their respective market, and are sensitive to 
316 external financing. Further, there is concentrated ownership of equity in the firms 317 operating in each sector. As such, we conclude that the "Financial Giants" have the 318 potential to influence corporate strategy in the Amazon and boreal forests. and transformation

322 Despite limitations in available financial data, our methodology allows us to identify

323 key financial actors with influence over economic activities modifying biomes

324 associated with tipping elements in the Earth's climate system. The specific

325 stockholders listed are naturally related to the selection criteria imposed here, but the

326 interesting issue is the concept (and existence) of prevalent stockholders with the

327 hitherto unrealized influence on such tipping elements. While several of the prevalent

328 stockholders identified have indeed publicly acknowledged climate-related risks, we

329 argue that their continued substantial ownership in industries that impact on key

330 biomes and Earth system tipping elements suggests they "punch below their weight"

331 with regards to the promotion of corporate governance that bolsters the resilience of

332 these biomes.

334 The degree to which the influence of the "Financial Giants" can be used in favor of

335 climate stability is an issue deserving more attention by scholars interested in

336 exploring the role of financial flows for sustainability. For the financial institutions to

337 become change agents would require concerted action by a coalition of the financial

338 actors identified here. However, a number of possible factors could be seen as barriers

339 to an influence of this sort. 
341 The first is the comparatively marginal economic role the ownership in these

342 companies play for the portfolios of the identified prevalent stockholders. As an

343 example, while investments of one of the largest asset managers (\#1 in Table 2) in the

344 selected biomes and economic sectors are considerable (we estimate them to be USD

3458 billion), they represent only a fraction $(<0,01 \%)$ of the total assets under

346 management by this investor, estimated to be of a total value of USD 5.1 trillion

347 (BlackRock 2017). Furthermore, several actors in Table $2(\# 1, \# 2$, \#4, and \#7) are

348 commonly referred to as passive investors. These are investors who provide

349 investment vehicles that track a market index or a specific market segment, activities

350 which do not rely on active investment, such as voting and engaging. These investors

351 not only invest on behalf of their clients (such as pension funds), but are also often

352 assumed to lack incentives for exercising influence over individual companies, due to

353 associated costs. In addition, coordination problems and free-rider dynamics can arise

354 when the number of blockholders in any one company increases, decreasing

355 individual incentives to act (Dam and Scholtens 2013; Edmans 2014). Together, this

356 would imply that the identified financial actors might lack incentives to engage

357 actively.

359 However, there are two reasons to believe the influence of identified prevalent

360 stockholders is both considerable and possible. First, blockholders are, as already

361 noted, generally considered influential. Despite the fact that most passive investors

362 are characterized by investing small amounts in a multitude of companies to diversify

363 risk, Fichtner et al. (2017) show that several of the largest investment firms in the US

364 (including the "Big Three") are taking active steps toward more centralized 
stewardship and governance processes among their funds, which will allow them to maximize their voting power across all discretionary holdings. By pooling their funds' votes, the "Big Three" have been shown to vote against, and win over, short- and medium-term oriented investors at critical moments of decision-making (Appel et al. 2016; McCahery et al. 2016; Fichtner et al. 2017). Interestingly, recent analysis of the voting behavior of the "Big Three" show that these global investors tend to vote against proposals related to Environmental, Social and Governance (ESG) issues proposed by activist shareholders (Fichtner et al. 2017, pp. 21).

374 Second, institutional investors are expected to vote as part of their fiduciary duty to 375 counterbalance the power of company management. While fiduciary duty has most 376 often been interpreted by investors as seeking maximum financial returns on 377 investments for their beneficiaries, there is a growing perception that the fiduciary 378 duties of institutional investors should include sustainability considerations, even 379 though it remains a contested position (EU High-Level Expert Group on Sustainable 380 Finance 2018). Actors such as pension funds and asset managers also invest for the 381 long term, and at least some of the large investors are recognizing both their influence 382 and their responsibility (Fichtner et al. 2017). As several scholars have noted, such 383 investments in improved Environmental, Social and Governance criteria (ESG) may 384 also have financial benefits, thereby providing further incentives for engagement from 385 the side of stockholders (Margolis and Walsh 2003; Orlitzky et al. 2003; Dimson et 386 al. 2015; van Duuren et al. 2016). 


\section{Next steps}

389 Financial actors and flows play a key role in the global economy. Through their

390 influence over economic activities that modify biomes associated with tipping

391 elements, financial actors can also affect climate stability. Our analysis shows that a

392 subset of the global financial community plays a particularly important role in this

393 regard.

395 These insights are of relevance to scholars, financial actors and policy makers. First, 396 we bring to light the key role of large international institutional investors. Their

397 behavior and influence, as major blockholders in companies directly linked to

398 economic activities shaping ecosystems all over the world, have yet to be studied in

399 depth. Second, the approach and results presented here can provide further impetus

400 for research on how global actors, distant drivers and "telecouplings" affect the

401 climate system and the biosphere (Liu et al. 2015; Österblom et al. 2015; Scholtens 402 2017).

403

404 The methodology presented here could be applied to other economic sectors to link 405 companies and investors to other important biosphere functions. Such analyses could, 406 and should, be complemented with other financial data. Mapping the links between 407 financial actors and critical tipping elements in the climate and the broader Earth 408 system opens up a range of new and important questions. Can fiduciary duty include 409 damages to global environmental commons, affecting millions of people for 410 generations to come? How large are the material risks associated with non-linear 411 changes in these critical biomes, including their climate repercussions? What 
412 economic, political and social pressures shape the investment and corporate

413 engagement behavior of "Financial Giants"? And does their voting behavior and

414 ownership engagement differ across sectors, including those associated with biomes

415 critical for alternative trajectories of the Earth system (Steffen et al. 2018)?

416

417 Questions such as these require increased attention as scholars, financial institutions, 418 policy-makers and civil society move forward to address the risks entailed with rapid 419 global environmental change. 


\section{References}

421 Appel IR, Gormley TA, and Keim DB. 2016. Passive investors, not passive owners. $J$ financ econ 121: 111-41.

Barnosky AD, Hadly EA, Bascompte J, et al. 2012. Approaching a state shift in Earth's biosphere. Nature 486: 52-8.

Battiston S, Mandel A, Monasterolo I, et al. 2017. A climate stress-test of the financial system. Nat Clim Chang 7: 283-8.

BlackRock. 2017. Official website.https://www.blackrock.com. Viewed 25 Sep 2017.

Booth L, Aivazian V, Demirguc-Kunt A, and Maksimovic V. 2001. Capital structures in developing countries. J Finance 56: 87-130.

430 Bureau van Dijk. 2017. Orbis databasehttps://orbis.bvdinfo.com. Viewed 18 May $431 \quad 2017$.

432 Chatterjee S, Fabian N, and Feller E. 2016. Greening institutional investment. UN PRI and UNEP FI Input Paper.

434 Collier B, Skees J, and Barnett B. 2009. Weather index insurance and climate change: 435 Opportunities and challenges in lower income countries. Geneva Pap Risk Insur 436 Issues Pract 34: 401-24.

437 Cornell SE, Prentice IC, House JI, and Downy CJ. 2012. Understanding the earth 438 system: global change science for application. Cambridge University Press.

439 Dam L and Scholtens B. 2013. Ownership concentration and CSR policy of European $440 \quad$ multinational enterprises. J Bus Ethics 118: 117-26.

441 Damodaran A. 2017. Debt Ratio Trade Off Variables by Industry, Data 442 Archives.http://people.stern.nyu.edu/adamodar/New_Home_Page/dataarchived.h tml. Viewed 2 Jul 2018. 
444 Dimson E, Karakaş O, and Li X. 2015. Active ownership. Rev Financ Stud 28: 3225$445 \quad 68$.

446 Duuren E van, Plantinga A, and Scholtens B. 2016. ESG integration and the 447 investment management process: fundamental investing reinvented. J Bus Ethics $448 \quad$ 138: $525-33$.

449 Edmans A. 2014. Blockholders and Corporate Governance. Annu Rev Financ Econ 6: $450 \quad 23-50$

451 EU High-Level Expert Group on Sustainable Finance. 2018. Financing a Sustainable $452 \quad$ European Economy. Brussels.

453 Fichtner J, Heemskerk EM, and Garcia-Bernardo J. 2017. Hidden power of the Big 454 Three? Passive index funds, re-concentration of corporate ownership, and new 455 financial risk. Bus Polit 19: 298-326.

456 Flannery MJ, Kwan SH, and Nimalendran M. 2004. Market evidence on the 457 opaqueness of banking firms' assets. J financ econ 71: 419-60.

458 Galaz V, Crona B, Dauriach A, et al. 2018. Tax havens and global environmental 459 degradation. Nat Ecol Evol.

460 Galaz V, Gars J, Moberg F, et al. 2015. Why ecologists should care about financial $461 \quad$ markets. Trends Ecol Evol 30: 571-80.

462 Geist HJ and Lambin EF. 2002. Proximate cause and underlying driving forces of $463 \quad$ tropical deforestation. Bioscience 52: 143-50.

464 Lawrence D and Vandecar K. 2015. Effects of tropical deforestation on climate and $465 \quad$ agriculture. Nat Clim Chang 5: 27-36.

466 Lenton TM, Held H, Kriegler E, et al. 2008. Tipping elements in the Earth's climate 467 system. Proc Natl Acad Sci 105: 1786-93.

468 Lenton TM and Williams HTP. 2013. On the origin of planetary-scale tipping points. 
470 Liu J, Mooney H, Hull V, et al. 2015. Systems integration for global sustainability.

$471 \quad$ Science 347: 1258832.

472 Margolis JD and Walsh JP. 2003. Misery loves companies: Rethinking social $473 \quad$ initiatives by business. Adm Sci $Q$ 48: 268-305.

474 Mayer C. 1990. Financial systems, corporate finance, and economic development. In: 475 Asymmetric information, corporate finance, and investment. University of $476 \quad$ Chicago Press.

477 McCahery JA, Sautner Z, and Starks LT. 2016. Behind the scenes: The corporate 478 governance preferences of institutional investors. J Finance 71: 2905-32.

479 Morgan DP. 2002. Rating banks: Risk and uncertainty in an opaque industry. Am $480 \quad$ Econ Rev 92: 874-88.

481 Müller B and Kreuer D. 2016. Ecologists should care about insurance, too. Trends $482 \quad$ Ecol Evol 31.

483 OECD. 2017. Mobilising bond markets for a low-carbon transition. Paris.

484 Orlitzky M, Schmidt FL, and Rynes SL. 2003. Corporate social and financial 485 performance: A meta-analysis. Organ Stud 24: 403-41.

486 Österblom H, Jouffray JB, Folke C, et al. 2015. Transnational corporations as 487 "keystone actors" in marine ecosystems. PLoS One 10: e0127533.

488 Rajan RG and Zingales L. 1995. What do we know about capital structure? Some 489 evidence from international data. J Finance 50: 1421-60.

490 Revelli C and Viviani JL. 2015. Financial performance of socially responsible 491 investing (SRI): What have we learned? A meta-analysis. Bus Ethics 24: 158-85. 492 Rockström J, Gaffney O, Rogelj J, et al. 2017. A roadmap for rapid decarbonization. 493 Science 355: 1269-71. 
494 Rockström J, Steffen JW, Noone K, et al. 2009. Planetary boundaries: Exploring the safe operating space for humanity. Ecol Soc 14: 32.

496 Schellnhuber HJ, Rahmstorf S, and Winkelmann R. 2016. Why the right climate target was agreed in Paris. Nat Clim Chang 6: 649-53.

Scholtens B. 2017. Why finance should care about ecology. Trends Ecol Evol: In press.

Sievänen R, Rita H, and Scholtens B. 2013. The Drivers of Responsible Investment: The Case of European Pension Funds. J Bus Ethics 117: 137-51.

Snyder PK, Delire C, and Foley JA. 2004. Evaluating the influence of different vegetation biomes on the global climate. Clim Dyn 23: 279-302.

505

Steffen W. 2006. The Anthropocene, global change and sleeping giants: where on Earth are we going? Carbon Balance Manag 1: 3.

506
Steffen W, Richardson K, Rockström J, et al. 2015. Planetary boundaries: Guiding human development on a changing planet. Science 347: 1259855.

Steffen W, Rockström J, Richardson K, et al. 2018. Trajectories of the Earth System in the Anthropocene. Proc Natl Acad Sci US A in press: 201810141.

Steffen W, Sanderson RA, Tyson PD, et al. 2004. Global change and the earth system: a planet under pressure. Springer Science \& Business Media.

Stiroh KJ. 2006. New evidence on the determinants of bank risk. J Financ Serv Res 30: $237-63$.

UNEP Inquiry. 2016. Government Subsidies to the Global Financial System: A Preliminary Exploration.

Vitali S, Glattfelder JB, and Battiston S. 2011. The network of global corporate control. PLoS One 6: e25995.

West PC, Narisma GT, Barford CC, et al. 2011. An alternative approach for 
520 Worm B and Paine RT. 2016. Humans as a hyperkeystone species. Trends Ecol Evol $521 \quad 31: 600-7$.

522 WWF and EnviroMarket. 2012. Palm oil investor review: Investor guidance on palm $523 \quad$ oil. : $1-44$. 
Figure 1. Threshold dynamics in selected tipping elements.

See separate JPG files.

Figure 1a. Amazon region. Deforestation in the Amazon region has been a well-

529 known challenge for climate policy for decades. The Amazon biome has been

530 proposed to contain a tipping point beyond which increasing deforestation could lead

531 to an abrupt shift from rainforests to savannas and possibly to the emergence of a

532 semi-desert area (in the driest portion of Northeast Brazil) with detrimental

533 implications for both the regional and global climate. Symbols display main

534 environmental and socio-economic drivers.

535 Figure 1b. Boreal forests. The world's forests both dampen or amplify

536 anthropogenic climate change through forest-climate interactions and exchanges of

537 energy, water, and $\mathrm{CO}_{2}$. Boreal forests play a critical role in the climate system by

538 affecting the surface albedo. It has been proposed that these forests have a significant

539 biogeophysical effect on annual mean global temperature. Symbols display main

540 environmental and socio-economic drivers. See Supporting Information (1) for details

541 including references.

544 Figure 2. Total ownership by the 16 prevalent stockholders in selected companies 
548 See separate PDF files.

549

550 Figure 2 shows the percentage of stock ownership of prevalent stockholders, the "Big

551 Three" and the largest stockholder in each company (bar charts). For each sector, it

552 also shows the total market share controlled by selected companies (pie charts). See

553 Supporting Information (2) for methodological details.

554

555

556 


\section{Tables}

558 Table 1. Market share held by the top 4 publicly listed and the top 4 private and

559 other companies in each sector (\%).

\begin{tabular}{|c|c|c|c|}
\hline Sector & $\begin{array}{c}\text { Top 4 publicly } \\
\text { listed companies }\end{array}$ & $\begin{array}{c}\text { Top 4 private } \\
\text { and other } \\
\text { companies }\end{array}$ & $\begin{array}{c}\text { Sum of the top 4 } \\
\text { public and top 4 non- } \\
\text { public companies }\end{array}$ \\
\hline Brazil, Beef & $70.4 \%$ & $10.7 \%$ & $81.0 \%$ \\
\hline Brazil, Soy & $29.0 \%$ & $32.0 \%$ & $60.9 \%$ \\
\hline $\begin{array}{c}\text { Canada, Wood, pulp and } \\
\text { paper }\end{array}$ & $23.4 \%$ & $12.1 \%$ & $35.5 \%$ \\
\hline $\begin{array}{c}\text { Russia, Wood, pulp and } \\
\text { paper }\end{array}$ & $21.3 \%$ & $45.6 \%$ & $66.9 \%$ \\
\hline
\end{tabular}

560

561 Note: The table is based on data from the top 100 companies in each sector (top 50 in

562 Russia). 'Private and other' include private companies, state-owned companies,

563 cooperatives, First Nations, and similar. See Supporting Information (3) for details. 
Table 2. List of financial institutions with ownership in the selected companies in

all selected regions and sectors

\begin{tabular}{|c|c|c|c|c|c|c|}
\hline $\mathbf{N r}$ & Stockholder & $\begin{array}{l}\text { Location of } \\
\text { headquarters }\end{array}$ & $\begin{array}{l}\text { Category of } \\
\text { stockholder }\end{array}$ & $\begin{array}{l}\text { Ownership } \\
\text { breadth }^{\text {a }}\end{array}$ & $\begin{array}{l}\text { Number } \\
\text { of } \\
\text { holdings } \\
\geq \mathbf{5 \%}\end{array}$ & $\begin{array}{l}\begin{array}{l}\text { Size of } \\
\text { ownership }\end{array} \\
\text { (million } \\
\text { USD) }\end{array}$ \\
\hline 1 & Blackrock & $\begin{array}{l}\text { United States } \\
\text { of America }\end{array}$ & $\begin{array}{l}\text { Investment } \\
\text { management firm }\end{array}$ & 18 & 7 & 8,076 \\
\hline 2 & Vanguard & $\begin{array}{l}\text { United States } \\
\text { of America }\end{array}$ & $\begin{array}{l}\text { Investment } \\
\text { management } \\
\text { firm/Mutual funds }\end{array}$ & 18 & 6 & 6,853 \\
\hline 3 & $\begin{array}{l}\text { Norway (via } \\
\text { Norges bank } \\
\text { and other } \\
\text { funds) }\end{array}$ & Norway & $\begin{array}{l}\text { State/Bank/Pension } \\
\text { fund/Sovereign } \\
\text { wealth fund }\end{array}$ & 18 & 0 & 2,193 \\
\hline 4 & $\begin{array}{l}\text { Dimensional } \\
\text { Fund } \\
\text { Advisors }\end{array}$ & $\begin{array}{l}\text { United States } \\
\text { of America }\end{array}$ & $\begin{array}{l}\text { Investment } \\
\text { management } \\
\text { firm/Mutual funds }\end{array}$ & 17 & 0 & 1,151 \\
\hline 5 & Credit Suisse & Switzerland & $\begin{array}{l}\text { Bank/Investment } \\
\text { management firm }\end{array}$ & 12 & 1 & 422 \\
\hline 6 & $\begin{array}{l}\text { Bank of New } \\
\text { York Mellon }\end{array}$ & $\begin{array}{l}\text { United States } \\
\text { of America }\end{array}$ & $\begin{array}{l}\text { Investment } \\
\text { management } \\
\text { firm/Bank }\end{array}$ & 12 & 0 & 1,188 \\
\hline 7 & State Street & $\begin{array}{l}\text { United States } \\
\text { of America }\end{array}$ & $\begin{array}{l}\text { Investment } \\
\text { management } \\
\text { firm/Bank }\end{array}$ & 11 & 2 & 4,804 \\
\hline 8 & AXA & France & $\begin{array}{l}\text { Insurance/Investment } \\
\text { management firm }\end{array}$ & 10 & 1 & 890 \\
\hline 9 & $\begin{array}{l}\text { JPMorgan } \\
\text { Chase \& Co }\end{array}$ & $\begin{array}{l}\text { United States } \\
\text { of America }\end{array}$ & $\begin{array}{l}\text { Bank/Investment } \\
\text { management firm }\end{array}$ & 10 & 0 & 1,123 \\
\hline 10 & $\begin{array}{l}\text { Principal } \\
\text { Financial }\end{array}$ & $\begin{array}{l}\text { United States } \\
\text { of America }\end{array}$ & $\begin{array}{l}\text { Investment } \\
\text { management firm }\end{array}$ & 10 & 0 & 402 \\
\hline 11 & $\begin{array}{l}\text { Deutsche } \\
\text { Bank }\end{array}$ & Germany & $\begin{array}{l}\text { Bank/Investment } \\
\text { management firm }\end{array}$ & 10 & 0 & 356 \\
\hline 12 & $\begin{array}{l}\text { Fidelity } \\
\text { Management } \\
\text { \& Research }\end{array}$ & $\begin{array}{l}\text { United States } \\
\text { of America }\end{array}$ & $\begin{array}{l}\text { Investment } \\
\text { management } \\
\text { firm/Mutual funds }\end{array}$ & 9 & 3 & 3,200 \\
\hline 13 & $\begin{array}{l}\text { Stichting } \\
\text { Pensioenfonds } \\
\text { ABP } \\
\text { (National } \\
\text { Civil Pension } \\
\text { Fund) }\end{array}$ & $\begin{array}{l}\text { The } \\
\text { Netherlands }\end{array}$ & Pension fund & 9 & 0 & 646 \\
\hline 14 & $\begin{array}{l}\text { Franklin } \\
\text { Templeton } \\
\text { Investments }\end{array}$ & $\begin{array}{l}\text { United States } \\
\text { of America }\end{array}$ & $\begin{array}{l}\text { Investment } \\
\text { management firm }\end{array}$ & 5 & 0 & 1,641 \\
\hline 15 & Van Eck & $\begin{array}{l}\text { United States } \\
\text { of America }\end{array}$ & $\begin{array}{l}\text { Investment } \\
\text { management firm }\end{array}$ & 5 & 0 & 337 \\
\hline 16 & $\begin{array}{l}\text { Russell } \\
\text { Investments }\end{array}$ & $\begin{array}{l}\text { United States } \\
\text { of America }\end{array}$ & $\begin{array}{l}\text { Investment } \\
\text { management firm }\end{array}$ & 5 & 0 & 93 \\
\hline
\end{tabular}


571 Note: ${ }^{\text {a) }}$ Ownership breadth is defined as the number of companies in which a

572 stockholder is invested (Fichtner et al. 2017), out of the 29 companies studied.

573 b) Size of ownership is calculated as the product between the market capitalization of 574 the listed company and the percentage of shares directly or indirectly owned by the 575 stockholder. 
Table 3. Concentration of equity ownership in each publicly listed company,

measured by the Herfindahl-Hirschman index (HHI)

\begin{tabular}{|c|c|c|c|}
\hline Sector & Company & HHI & $\begin{array}{l}\text { Average } \\
\text { HHI per } \\
\text { sector }\end{array}$ \\
\hline \multirow{3}{*}{ Brazil, Beef } & JBS & 4938 & \multirow{3}{*}{2546} \\
\hline & Marfrig & 1221 & \\
\hline & Minerva & 1478 & \\
\hline \multirow[t]{2}{*}{ Brazil, Soy } & $\begin{array}{l}\text { Archer Daniels } \\
\text { Midland }\end{array}$ & 292 & \multirow[t]{2}{*}{345} \\
\hline & Bunge & 398 & \\
\hline \multirow{10}{*}{$\begin{array}{l}\text { Canada, } \\
\text { Wood pulp } \\
\text { and paper }\end{array}$} & Canfor & 2904 & \multirow{10}{*}{1021} \\
\hline & Hokuetsu Kishu Paper & 542 & \\
\hline & Louisiana-Pacific & 384 & \\
\hline & Marubeni & 308 & \\
\hline & $\begin{array}{l}\text { Nippon Paper } \\
\text { Industries }\end{array}$ & 204 & \\
\hline & Norbord & 2640 & \\
\hline & Resolute Forest & 1415 & \\
\hline & $\begin{array}{l}\text { Products } \\
\text { Tembec }\end{array}$ & 1428 & \\
\hline & West Fraser & 192 & \\
\hline & Weyerhaeuser & 195 & \\
\hline \multirow{4}{*}{$\begin{array}{l}\text { Russia, Wood } \\
\text { pulp and } \\
\text { paper }\end{array}$} & International Paper & 306 & \multirow{4}{*}{2133} \\
\hline & Mondi Ltd. & 1308 & \\
\hline & Mondi plc & 1652 & \\
\hline & Sistema & 5265 & \\
\hline
\end{tabular}

578

579 Note: The HHI index is computed as the sum of squared ownership (in \%). Its

580 theoretical maximum is 10,000 (monopoly), and its theoretical minimum is

581 approaching zero (pure competition) (Rhoades, 1993). Note that only shareholders

582 with shares of at least $0.01 \%$ appear in our data. 
Table 4. Total book debt to capital of all selected companies, presented per sector

584 and compared to industry averages (2016)

\begin{tabular}{llll}
\hline Sector & $\begin{array}{l}\text { Book debt } \\
\text { to capital }\end{array}$ & \multicolumn{1}{c}{$\begin{array}{c}\text { Industry total book debt to capital } \\
\text { (Damodaran 2017) }\end{array}$} & \\
\hline $\begin{array}{l}\text { Beef } \\
\text { Brazil }\end{array}$ & $73.7 \%$ & Food processing, Emerging markets & $40.1 \%$ \\
\hline $\begin{array}{l}\text { Soy } \\
\text { Brazil }\end{array}$ & $25.4 \%$ & Farming/Agriculture, Global & $49.1 \%$ \\
\hline $\begin{array}{l}\text { Wood, pulp and paper } \\
\text { Canada }\end{array}$ & $56.5 \%$ & Paper/Forest Products, Global & $45.6 \%$ \\
\hline $\begin{array}{l}\text { Wood, pulp and paper } \\
\text { Russia }\end{array}$ & $53.9 \%$ & Paper/Forest Products, Global & $45.6 \%$ \\
\hline
\end{tabular}

586 Note: The total book debt to capital ratio is calculated as the ratio between the book

587 value of long-term and short-term debt and the sum between book value of long-term

588 and short-term debt and the book value of shareholders' equity, following the

589 methodology adopted by Damodaran (2017). See Supporting Information (5) for

590 details. 